\title{
22 Small-scale renewable energy as a catalyst for advancing agriculture and food security in Southern Africa
}

\author{
Jon Padgham and Mariama Camara
}

\section{Introduction}

Energy poverty is a key determinant of under development and constrained economic performance across Africa. Approximately 620 million people lack access to electricity and 790 million cook with traditional biomass on unimproved cookstoves, which contributes substantially to land degradation (REN, 2018). With the exception of South Africa, less than $30 \%$ of Southern Africa's population has access to electricity and there is strong reliance on traditional biomass fuel for cooking and heating (Mabhaudhi et al., 2018). Given the current situation of low energy access, Africa will not meet the UN 2030 Sustainable Development Goal (SDG) target of universal access to energy until 2080 and access to clean energy for cooking until the middle of the next century (Africa Progress Report, 2015). Meeting that SDG 7 goal of universal energy access would require Africa to spend between US $\$ 41$ and US $\$ 55$ billion per year on energy and infrastructure investment; by contrast current annual expenditures are about US $\$ 8$ billion (Chirambo, 2018).

Sole reliance on a conventional "hard path" to energy development, characterized by high fossil fuel use and a centralized grid, is becoming increasingly untenable as extreme climatic events intensify and technical and market innovations render renewable energy sources delivered on a decentralized grid, or off grid, much more attainable (Africa Progress Report, 2015). Renewable energy in its various forms - solar, hydro, wind and bioenergy - represent an increasingly viable option for at least partially leapfrogging traditional centralized, fossil fuel energy development on the continent (van der Zwann et al., 2018). The scale of these renewable energy forms can vary from macro, gridconnected enterprises to micro, off-grid local applications.

Increasing energy access and rural electrification in Africa is essential for triggering broader gains in agricultural productivity and food security. In remote rural areas, small-scale distributed renewable energy systems offer a more feasible pathway to electrification than large-scale, grid-connection energy sources (Diaz-Maurin et al., 2018). Because of the applicability to lowincome rural environments, micro off-grid applications will form the basis for 
this paper's review and analysis. The paper will focus on solar photovoltaic energy and bioenergy, and both of these energy sources will be examined in the context of rural development and its linkages to food production and food security.

\section{Renewable energy types}

\section{Solar photovoltaics}

Over the past several years, there has been a steady increase in renewable energy investments in Africa, with this trend mostly attributable to favourable shifts in access to solar energy, driven by falling prices for photovoltaics and the spread of technological and market innovations. These include large investments in solar arrays as well as uptake of micro-grid, nano-grid and off-grid solar power sources. Globally, solar photovoltaic module prices have fallen more than $75 \%$ since 2009 (Chirambo, 2018).

Africa has the highest photovoltaic solar energy potential of all the world's regions (Figure 22.1); in Southern Africa solar power potential is approximately 20,000 terawatt-hours per year. There is significant potential for expanding solar energy in the region, given that current installed solar capacity in Southern Africa is less than 1\% of that potential (Jadhave et al., 2017). Approaching these potentials would require massive infrastructure investments and policy shifts, strengthening of private and public institutions and changes in incentive structures that would make solar more accessible to lowincome consumers.

While Southern Africa is far off from achieving kind of production potential, positive signs of change are increasingly evident across the sub-region and

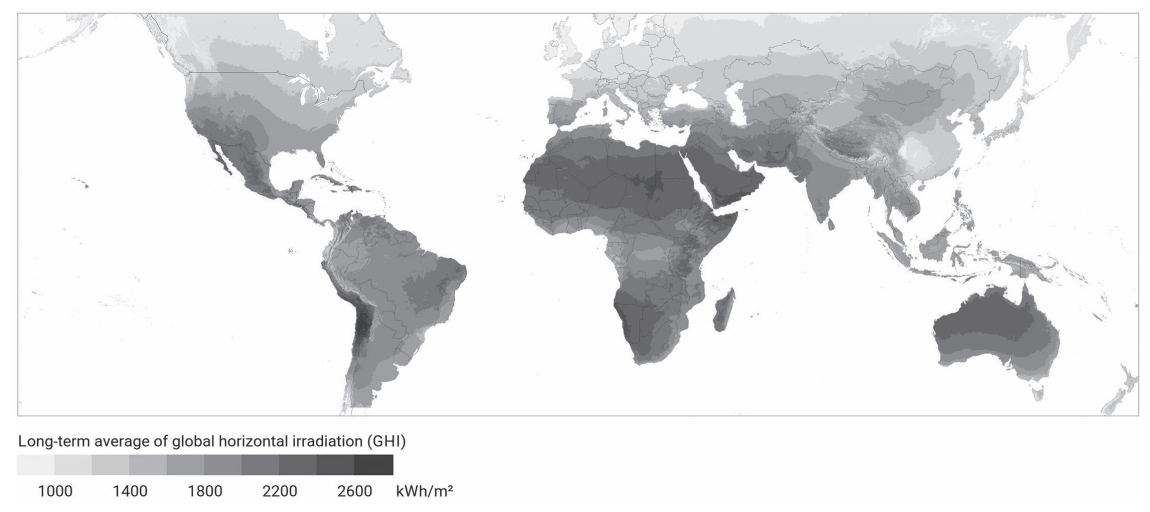

Figure 22.1 Photovoltaic power potential

Source: Solargis 
elsewhere across Africa, ranging from foreign and domestic investments in large-scale solar arrays to new technical and business models that have allowed the emergence of pico-scale solar schemes (REN, 2018). There is strong growth potential in solar PV to serve decentralized energy needs, particularly in rural areas that lack access to the grid and where infrastructure for power transmission is costly and unreliable (Ikejemba et al., 2017). Market innovations for off-grid applications, such as pay-as-you-go (PAYG), based on mobile payment schemes and "plug and play" for solar household systems, have accounted for robust growth in Africa's renewable energy sector over the last several years (Ulsrud et al., 2018). Growth of off-grid solar has been faster in East and West Africa compared with Southern Africa; the exception is South Africa, which, together with Kenya, has had the most rapid growth in cumulative non-hydropower renewable energies. East Africa, and in particular Kenya, has seen strong capital inflows into the off-grid market.

\section{Bioenergy}

\section{Crop biofuels}

First-generation biofuels in the form of bioethanol from starch sources (e.g., sugarcane, molasses, cassava and cereal crops) and biodiesel production from oilseeds (e.g., soya, oil palm and Jatropha) offer potential for wide-scale bioenergy production in Africa. However, while biofuel production can generate positive energy security and economic growth outcomes, biofuel crop production in Africa also carries significant downside risks related to environmental and social sustainability, including competition for land and water between fuel and food crops, contractual and regulatory obligations that expose farmers to legal risks, changes in land tenure security and extension of agriculture into forested areas to compensate for land lost to biofuel crops (Goetz et al., 2017; Pradhan and Mbohwa, 2014). Recent research in Southern Africa indicates that the type and production method of biofuel can influence whether biofuel production increases or decreases terrestrial carbon stocks (Romeu-Dalmau et al., 2018). Efforts to address crop-biofuel sustainability challenges have been lackluster due to lack of policy responses that go beyond the production potential of biofuels to adequately consider the social and environmental costs of biofuel production (Goetz et al., 2017).

\section{Waste biogas}

Biogas offers a promising addition to the biofuels portfolio, and one that is unencumbered by the social and environmental downsides associated with biofuel crops. Biogas has gained a foothold in Asia and India and is viewed as having potential for dealing with environmental and sanitation issues presented 
by excessive livestock, agricultural and municipal waste in sub-Saharan Africa, while providing energy to rural environments. Domestic biogas digesters (floating drum and fixed dome types) offer multiple benefits for lighting and cooking, which reduces workloads of women and girls and their exposure to indoor pollution, and residues can be used as biofertilizers to increase soils fertility (IRENA, 2017a, 2017b). However, uptake and upscaling of biogas production and use in Sub-Saharan Africa has been uneven. Key barriers to uptake include a lack of 1) socioeconomic and cultural considerations in project development; 2) technicians for maintaining technology; 3) literacy and awareness of users; and 4) funding and subsidies for widespread dissemination of technologies. In South Africa, there is the additional constraint of low efficiency and cost competitiveness of biogas compared with fossil fuels (Mukumba et al., 2016).

\section{Applications of renewable energy to food systems and rural development}

Higher rates of energy access and rural electrification in Africa is essential for triggering broader gains in agricultural productivity and food and nutritional security, primarily through increasing access to irrigation, improving food storage and safety and value-added processing. Access to energy can also begin to reduce tightly locked seasonal dependencies associated with smallholder rainfed agriculture. In addition to improving food security, expanding energy access produces a wide array of development benefits linked to stimulating economic growth, improving educational performance and producing better health and gender equality outcomes (Chirambo, 2018).

Use of off-grid and micro-grid solar photovoltaics offers a scale-appropriate technology to expand irrigation in rural areas not connected to grid energy (Hartung and Pluschke, 2018; Wazed et al., 2018). The technology generally consists of photovoltaic panels connected to a pump, set up to an elevated tank or reservoir and adapted for different irrigation types, such as flood, sprinkler or drip irrigation. (The system is analogous to many diesel-powered systems commonly encountered in smallholder farming in Africa.) Increasing access to solar irrigation technologies can spur diversification of cropping systems towards higher-value crops, bring greater stabilization of yields and extend the agricultural season beyond the bounds of the rainy season. Furthermore, solar pumps improve access to household water where economic water scarcity and frequent droughts are high, and the continued decline in the price of photovoltaic components, combined with innovations in finance, has meant that clean cooking systems powered by solar (as well as biogas) are becoming increasingly price competitive with dirty conventional cooking fuel sources (Batchelor et al., 2018). All of these factors are important for rural development, particularly in the context of accelerating warming trends and increasing prevalence of drought in Southern Africa. 
However, as with any technology that enlarges water access, widespread use of solar irrigation systems runs the risk of unsustainable water use given that there is no financial signal via a cost per unit of power as with the case with petrol or grid-based energy sources (Hartung and Pluschke, 2018). An integrated approach to solar powered irrigation is required, one that considers access to appropriate financing schemes, the economic viability of solar irrigation systems (and payback time) related to potential for high-value horticultural crops and access to vibrant markets, as well as agronomic practices that promote water conservation and use efficiency.

Increasing food security requires a systems approach that goes beyond a focus on higher crop yields. In particular, postharvest food losses in Africa, estimated at over one-third of its agricultural production, need greater attention. Postharvest technologies require energy to operate, and in much of rural Africa traditional fuels such as firewood and dung cakes are used, resulting in only rudimentary forms of storing and processing. Having access to modern and reliable sources of energy can speed up the adoption of improved storage and processing technologies and foster growth of agro-enterprises. For example, in East Africa appropriate technology pilot efforts are underway, utilizing biogas to provide cold storage for dairy producers, infrared technologies to speed up coffee drying and biogas-powered steam engines to power ancillary food processing for fruit and vegetable drying, grain mills, irrigation and refrigeration (IRENA, 2018). This effort has reduced food losses by $80 \%$ for high-value but highly perishable foods. Pilots are also underway in East Africa to use biogas for clean cooking, an important contribution to reducing chronic respiratory and other health concerns associated with use of traditional solid biomass for cooking.

\section{Identifying and addressing constraints to small-scale renewable energy in Africa}

While energy access can usher in food productivity and security gains, processes for broader rural transformation depend on structural changes shaped by linkages between agriculture, the rural nonfarm economy, manufacturing, infrastructure, finance and services. Realizing the potential of solar and other forms of renewable energy in Africa will require overcoming important obstacles and bottlenecks that extend well beyond technological issues. These include: 1) poor governance (incoherent and inconsistent policies, inadequate planning and implementation, political agendas, lack of transparency in how energy projects are awarded, etc.);2) lack of technical skills to support maintenance and management of implemented projects; and 3) economic and social disincentives related to lack of community involvement, informational and financial barriers and economic interests linked to carbon-intensive energy sources (Baptista and Plananska, 2017; Ikejemba et al., 2017; Morrissey, 2017; Ulsrud et al., 2018). 
Table 22.1 Key attributes of solar and biogas renewable energy forms

\begin{tabular}{|c|c|c|c|}
\hline $\begin{array}{l}\text { Applications to } \\
\text { agriculture and food } \\
\text { security }\end{array}$ & Development outcomes & Key enabling factors & $\begin{array}{l}\text { Needs for addressing } \\
\text { constraining factors }\end{array}$ \\
\hline $\begin{array}{l}\text { Irrigation expansion } \\
\text { Cold storage } \\
\text { Value-added } \\
\text { processing } \\
\text { Agro-diversification } \\
\text { to high-value } \\
\text { crops }\end{array}$ & $\begin{array}{l}\text { Reduced sensitivity } \\
\text { to dry spells } \\
\text { Reduced } \\
\text { postharvest } \\
\text { storage losses } \\
\text { Increased food } \\
\text { safety } \\
\text { Clean fuel source } \\
\text { for cooking } \\
\text { Increased income } \\
\text { generation }\end{array}$ & $\begin{array}{l}\text { Increased cost } \\
\text { effectiveness } \\
\text { Flexible and scale- } \\
\text { appropriate } \\
\text { technology } \\
\text { Potential to tap } \\
\text { into climate } \\
\text { finance schemes } \\
\text { for funding } \\
\text { Strong potential } \\
\text { for growth } \\
\text { in the private } \\
\text { sector }\end{array}$ & $\begin{array}{l}\text { Appropriate financing } \\
\text { schemes to address } \\
\text { affordability gap } \\
\text { Bottom-up needs and } \\
\text { priorities to inform } \\
\text { a more enabling } \\
\text { policy environment } \\
\text { for renewable } \\
\text { energy in rural areas } \\
\text { Capacity building } \\
\text { in finance, } \\
\text { private sector } \\
\text { and technological } \\
\text { skills for energy } \\
\text { installation and use } \\
\text { More research } \\
\text { to understand } \\
\text { sociocultural and } \\
\text { economic incentives } \\
\text { and disincentives } \\
\text { Integration of } \\
\text { renewable energy } \\
\text { frameworks with } \\
\text { investments in } \\
\text { market creation and } \\
\text { rural infrastructure } \\
\text { needs }\end{array}$ \\
\hline
\end{tabular}

In conclusion, the potential for small-scale renewable energy is quite good, particularly in the case of solar photovoltaics. Falling unit prices for solar, emergence of innovative financing schemes involving the private sector, availability of large-scale financial mechanisms, such as the Green Climate Fund, and the inherent flexibility of the technology are all key factors in increasing the viability of solar power in off-grid and micro-grid systems. However, there are important constraining factors as well related to technical and financial capacities, institutions and governance and policy levers that need greater understanding in order to realize the potential of solar and other forms of renewable energy.

\section{References}

Africa Progress Report (2015) Power, People, Planet. Seizing Africa's Energy and Climate Opportunities, Africa Progress Panel. ISBN 978-2-9700821-6-3. 
Baptista, I. and Plananska, J. (2017) 'The landscape of energy initiatives in sub-Saharan Africa: Going for systemic change or reinforcing the status quo?', Energy Policy, vol 110, pp. 1-8.

Batchelor, S., Brown, E., Leary, J., Scott, N., Alsop, A. and Leach, M. (2018) 'Solar electric cooking in Africa: Where will the transition happen first?' Energy Research and Social Science, vol 40, pp. 257-272.

Chirambo, D. (2018) 'Towards the achievement of SDG 7 in sub-Saharan Africa: Creating synergies between Power Africa, Sustainable Energy for All and climate finance in-order to achieve universal energy access before 2030', Renewable and Sustainable Energy Reviews, vol 94, pp. 600-608.

Diaz-Maurin, F, Chiguvare, Z. and Gope, G. (2018) 'Scarcity in abundance: The challenges of promoting energy access in the Southern African region', Energy Policy, vol 120, pp. 110-120.

Goetz, A., German, L., Hunsberger, C., Schmidt, O. (2017) 'Do no harm? Risk perceptions in national bioenergy policies and actual mitigation performance', Energy Policy, vol 108, pp. $776-790$.

Hartung, H. and Pluschke, L. (2018) 'The benefits and risks of solar-powered irrigation A global overview', United Nations Food and Agriculture Organization.

Ikejemba, E.C., Schuur, P.C., Van Hillegersberg, J. and Mpuan, P. B. (2017) 'Failures and generic recommendations towards the sustainable management of renewable energy projects in Sub-Saharan Africa', Renewable Energy, vol 113, pp. 639-647.

IRENA (2017a) Biofuel Potential in Sub-Saharan Africa: Raising Food Yields, Reducing Food Waste and Utilizing Residues, International Renewable Energy Agency, Abu Dhabi.

IRENA (2017b) Biogas for Domestic Cooking: Technology Brief, International Renewable Energy Agency, Abu Dhabi.

IRENA (2018) Sustainable Rural Bioenergy Solutions in Sub-Saharan Africa: A Collection of Good Practices, International Renewable Energy Agency, Abu Dhabi.

Jadhave, A.S., Chembe, D. K., Strauss., J. M. and Van Niekerk, J. L. (2017) 'Status of solar technology implementation in the southern African developing community (SADC) region', Renewable and Sustainable Energy Reviews, vol 73, pp. 622-631.

Mabhaudhi, T., Mpandeli, S., Nhamo, L., Chimonyo, V. G. P, Nhemachena, C., Senzanje, A., Naidoo, D., Modi, A. T. (2018) 'Prospects for improving irrigated agriculture in Southern Africa: Linking water, energy and food', Water, vol 10, 1881. doi:10.3390/w10121881

Morrissey, J. (2017) 'The energy challenge in sub-Saharan Africa: A guide for advocates and policy makers Part 2: Addressing energy poverty', Oxfam Research Backgrounder.

Mukumba, P., Makaka, G. and Mamphweli, S. (2016) 'Biogas technology in South Africa, problems, challenges and solutions', International Journal of Sustainable Energy and Environmental Research, vol 5, pp. 58-69.

Pradhan, A., Mbohwa, C. (2014) 'Development of biofuels in South Africa: challenges and opportunities', Renewable and Sustainable Energy Review, vol 39, pp. 1089-1100.

REN21. (2018) Renewables 2018 Global Status Report, Paris: REN21 Secretariat, ISBN 978-3-9818911-3-3.

Romeu-Dalmau, C., Gasparatos, A., von Maltitz, G., Graham, A., Almagro-Garcia, J., Wilebore, B. and Willis, K.J. (2018) 'Impacts of land use change due to biofuel crops on climate regulation services: Five case studies in Malawi, Mozambique and Swaziland', Agriculture, Ecosystems, and Environment, vol 246, pp. 314-324.

Ulsrud., K., Rohracher, H., Winther, T., Muchunku, C. and Palit, D. (2018) 'Pathways to electricity for all: What makes village-scale solar power successful?’ Energy Research \& Social Science, vol 44, pp. 32-40. 
van der Zwann, B., Kober, T., Longa, F. D., van der Laan, A. and Kramer, G. J. (2018) 'An integrated assessment of pathways for low-carbon development in Africa', Energy Policy, vol 117, pp. 387-395.

Wazed, S. M., Hughes, B. R., O’Connor, D. and Calautit, J. K. (2018) 'A review of sustainable solar irrigation systems for Sub-Saharan Africa', Renewable and Sustainable Energy Reviews, vol 81, pp. 1206-1225. 